\title{
INTEGRASI PENGUATAN PENDIDIKAN KARAKTER (PPK) DALAM PENYUSUNAN PERANGKAT PEMBELAJARAN PENDIDIKAN AGAMA HINDU DI SEKOLAH DASAR
}

\author{
Oleh \\ Ni Made Surawati \\ I Gusti Ayu Suasthi \\ Dosen Fakultas Pendidikan Agama dan Seni UNHI \\ surawati@unhi.ac.id
}

\begin{abstract}
ABSTRAK
Pendidikan karakter sudah selayaknya diutamakan dan dibudayakan di dalam dunia pendidikan. Penguatan Pendidikan Karakter (PPK) bukanlah suatu kebijakan baru karena telah menjadi gerakan nasional sejak tahun 2010. Proses pembelajaran pendidikan agama hindu dan budhi pekerti di sekolah dasar diawali dengan membuat perencanaan. Mulai dari menyusun silabus sampai pada tahap penyusunan RPP yang terintegrasi penguatan Pendidikan Karakter (PPK) di setiap pokok materi ajar.

Kata kunci: PPK, Proses Pembelajaran Pendidikan agama Hindu

ABSTRACT

Character in education should be prioritized and cultivated in the world of education. Character Education Strengthening (KDP) is not a new policy because it has become a national movement since 2010. The learning process of Hindu religion and culture in elementary schools begins with planning. Starting from compiling syllabus to the preparation stage of the RPP which is integrated in the strengthening of Character Education (PPK) in each subject matter of the teaching material.
\end{abstract}

Keywords: KDP, Learning Process Hinduism Education

\section{PENDAhuluan}

Undang-Undang Nomor 20 Tahun 2003 bermartabat dalam rangka mencerdaskan tentang Sistem Pendidikan Nasional telah kehidupan bangsa, bertujuan untuk menegaskan bahwa "Pendidikan nasional berkembangnya potensi peserta didik agar berfungsi mengembangkan kemampuan dan menjadi manusia yang beriman dan bertakwa membentuk watak serta peradaban bangsa yang kepada Tuhan Yang Maha Esa, berakhlak 
mulia, sehat, berilmu, cakap, kreatif, mandiri, mencanangkan sekaligus melaksanakan dan menjadi warga negara yang demokratis kebijakan Gerakan Nasional Pendidikan serta bertanggung jawab”. Selanjutnya, dalam Karakter berlandaskan Rencana Aksi Nasional Peraturan Pemerintah Nomor 19 Tahun 2005 (RAN) Pendidikan Karakter Bangsa. tentang Standar Nasional Pendidikan (SNP) Hal tersebut perlu dilanjutkan, juga terpapar secara tersurat berbagai dioptimalkan, diperdalam, dan bahkan kompetensi yang bersangkutan dengan karakter diperluas sehingga diperlukan penguatan di samping intelektualitas. Ini semua pendidikan karakter bangsa. Untuk itu, sejak menandakan bahwa sesungguhnya pendidikan sekarang perlu dilaksanakan Gerakan bertugas mengembangkan karakter sekaligus Penguatan Pendidikan Karakter (PPK) dengan intelektualitas berupa kompetensi peserta didik. mengindahkan asas keberlanjutan dan

Sehubungan dengan itu, penyelenggaraan kesinambungan. Gerakan PPK menempati pendidikan nasional terutama pendidikan dasar kedudukan fundamental dan strategis pada saat dan menengah dapat dikatakan sudah berada pemerintah mencanangkan revolusi karakter pada jalur yang tepat, karena telah memberikan bangsa sebagaimana tertuang dalam Nawacita pendidikan karakter sekaligus membentuk (Nawacita 8), menggelorakan Gerakan intelektualitas berupa kompetensi. Meskipun Nasional Revolusi Mental, dan menerbitkan demikian, proporsi penerapan pendidikan RPJMN 2014- 2019 berlandaskan Nawacita. karakter dengan pendidikan intelektual belum Sebab itu, Gerakan PPK dapat dimaknai berimbang akibat berbagai faktor. sebagai pengejawantahan Gerakan Revolusi

Usaha penyeimbangan pendidikan Mental sekaligus bagian integral Nawacita. karakter dengan pembentukan kompetensi Sebagai pengejawantahan Gerakan Nasional senantiasa harus dilakukan. Demi kepentingan Revolusi Mental sekaligus bagian integral masa depan bangsa Indonesia, bahkan sejak Nawacita, Gerakan PPK menempatkan sekarang perlu dilakukan pemusatan pendidikan karakter sebagai dimensi terdalam (centering) pendidikan karakter dalam atau inti pendidikan nasional sehingga penyelenggaraan pendidikan nasional pendidikan karakter menjadi poros pelaksanaan Indonesia. Kesadaran sekaligus usaha pendidikan dasar dan menengah.

pemusatan pendidikan karakter di jantung Lebih lanjut, Gerakan PPK perlu pendidikan nasional semakin kuat ketika pada mengintegrasikan, memperdalam, memperluas, tahun 2010 pemerintah Indonesia dan sekaligus menyelaraskan berbagai program 
dan kegiatan pendidikan karakter yang sudah dilaksanakan sampai sekarang. Dalam hubungan ini pengintegrasian dapat berupa karakter bangsa.

pemaduan kegiatan kelas, luar kelas di sekolah, dan luar sekolah (masyarakat/komunitas); merupakan jalan perwujudan Nawacita dan pemaduan kegiatan intrakurikuler, kokurikuler, Gerakan Revolusi Mental di samping menjadi dan ekstrakurikuler; pelibatan secara serempak inti kegiatan pendidikan yang berujung pada warga sekolah, keluarga, dan masyarakat; terciptanya revolusi karakter bangsa. perdalaman dan perluasan dapat berupa Menindaklanjuti kebijakan pemerintah tentang penambahan dan pengintensifan kegiatankegiatan yang berorientasi pada pengembangan karakter siswa, penambahan dan pemajanan kegiatan belajar siswa, dan pengaturan ulang waktu belajar siswa di sekolah atau luar sekolah; kemudian penyelerasan dapat berupa penyesuaian tugas pokok guru, Manajemen Berbasis Sekolah, dan fungsi Komite Sekolah dengan kebutuhan Gerakan PPK. Baik pada masa sekarang maupun masa akan datang, pengintegrasian, pendalaman, perluasan, dan penyelarasan program dan kegiatan pendidikan

\section{PEMbahasan}

\subsection{Hakekat Penguatan Pendidikan} Karakter (PPK)

Penguatan Pendidikan Karakter (PPK) mempunyai definisi gerakan pendidikan di sekolah untuk memperkuat karakter siswa. Gerakan pendidikan yang dimaksud melalui dikembangkan dari buku Desain Induk harmonisasi olah hati (etik), olah rasa (estetik), Pembangunan Karakter Bangsa 2010-2025 olah pikir (literasi), dan olah raga (kinestetik). (Pemerintah Republik Indonesia, 2010), antara Gerakan ini tentunya tak lepas dari dukungan lain: (1) Olah hati yaitu beriman dan bertakwa,
'Gerakan Nasional Karakter Bangsa', guru pendidikan agama hindu harus mampu mendesain pembelajaran pendidikan agama di sekolah dengan mengintegrasikan pendidikan karakter pada Perangkat pembelajaran yang dimilikinya. Baik pada silabus, RPP, kompetensi inti (KI), dan kompetensi dasar (KD), serta materi pembelajaran pendidikan agama disinkronkan dengan aspek-aspek nilai karakter. Dalam dokumen perencanaan pembelajaran (RPP), nilai-nilai karakter dinyatakan pada setiap pokok bahasan.

pelibatan publik dan kerjasama antara sekolah, keluarga, dan masyarakat yang merupakan bagian dari gerakan GNRM. (Kemendikbud, 2016). Perwujudan karakter individu yang bersumber dari hasil keterpaduan empat bagian karakter bangsa yang sesuai falsafah pancasila 
bersyukur, jujur, amanah, adil, tetib, sabar, rukun dengan penganut agama lain. Nilai disiplin, taat aturan, bertanggungjawab, karakter kedua adalah nasionalis. Nasionalis berempati, punya rasa iba, berani mengambil adalah sikap yang menunjukkan kesetiaan, resiko, pantang menyerah, menghargai kepedulian, dan penghargaan terhadap bahasa, lingkungan, rela berkorban, dan berjiwa lingkungan fisik, sosial, budaya, ekonomi, dan patriotiK, (2) Olah pikir yaitu cerdas, kritis, politik bangsa, serta menempatkan kepentingan kreatif, inovatif, analitis, ingin tahu, produktif, bangssa di atas kepentingan diri dan kelompok. berorientasi IPTEKS, dan reflektif, (3) Olah Nilai karakter yang ketiga adalah rasa yaitu kemanusiaan, saling menghargai, mandiri. Mandiri merupakan sikap tidak saling mengasihi, gotong royong, kebersamaan, bergantung pada orang lain, memanfaatkan ramah, peduli, hormat, toleran, nasionalis, tenaga, pikiran, waktu untuk merealisasikan komopolit, mengutamakan kepentingan umum, harapan, mimpi, dan cita-cita. Nilai karakter cinta tanah air, bangga menggunakan bhaasa keempat adalah gotong royong. Gotong royong dan produk Indonesia, dinamis, kerja keraas, mencerminkan tindakan menghargai kerja dan beretos kerja, (4) Olah raga yaitu bersih sama, saling membantu menyelesakan masalah dan sehat, sportif, tangguh, andal, berdaya bersama dan memberikan bantuan pada yang tahan, bersahabat, kooperatif, determininatif, membutuhkan. Nilai karakter kelima adalah kompetitif, ceria, ulet, dan gigih. integritas. Integritas adalah perilaku (Kemendikbud, 2016).

menjadikan diri agar selalu dipercaya, memiliki

PPK mengandung lima nilai karakter komitmen dan kesetiaan pada nilai-nilai utama yaitu religius, nasionalis, mandiri, kemanusiaan dan moral. gotong royong, dan integritas (Kemendikbud, 2016). Hal senada diungkapkan oleh Wilujeng (2016) bahwa masing-masing nilai karakter utama mempunyai sub-sub nilai karakter. Nilai karakter pertama adalah religius. Religius mencerminkan keimanan terhadap Tuhan Yang Maha Esa. Religius dapat diwujudkan melalui perilaku melaksanakan ajaran agama yang dianut, menghargai perpedaan agama, menjunjuang tinggi nilai toleransi, serta hidup

a. Ruang lingkup, Aspek-aspek, dan Standar Pengamalan Pendidikan Agama Hindu

Pendidikan Agama Hindu pada Sekolah Dasar mengajarkan konsep-konsep yang dapat menumbuhkan keyakinan agama peserta didik (kemendikbud,2016). Konsep-konsep tersebut meliputi:

1. Ruang lingkup Pendidikan Agama Hindu dan Budhi Pekerti adalah Tri 
Kerangka Agama Hindu yang diwujudkan melalui konsep Tri Hita Karana, yaitu

a. Hubungan manusia dengan Sang Hyang Widhi

b. Hubungan manusia dengan manusia lain

c. Hubungan manusia dengan lingkungan sekitar.

2. Aspek pendidikan agama hindu pada sekolah Dasar (SD) meliputi:

a. Pemahaman Kitab suci Veda yang menekankan kepada pemahaman Veda sebagai kitab suci, melalui pengenalan Kitab purana, Ramayana, Mahabharata, Bhagavadgita, Veda Sruti, smerti, dan mengenal bahasa yang digunakan dalam veda serta maharsi penerima wahyu veda dan maharsi pengkodifikasi veda

b. Tatwa merupakan pemahaman tentang sradha yang meliputi Brahman, atma, hokum karma, punarbhawa dan moksha

c. Susila yang penekanannya pada ajaran subhadan asubha karma, tri mala, tri kaya parisudha, catur paramitha, sad ripu, tri parartha, daiwi sampad dan asuri sampad, catur pataka, Tri hita karana dalam kehidupan dan catur guru sebagai ajaran bhakti serta tatwam asi yang merupakan ajaran kasih sayang antar sesame

d. Acara yang penekanannya pada sikap dan praktik sembahyang, yaitu dengan melafalkan lagu kidung keagamaan, memahami dasar wariga, jyotisa, tari sacral, orang suci, tempat suci, tri rna, serta mengenal panca yadnya.

e. Sejarah agama hindu menekankan pada pengetahuan sejarah perkembangan agama hindu dari india ke indonesia, sejarah agama hindu sebelum kemerdekaan, dan pemahaman sejarah agama.

\subsection{Kerangka Dasar Kurikulum}

Mengacu pada Permendikbud Nomor 57 tahun 2014 tentang kerangka dasar dan struktur Kurikulum Sekolah Dasar memuat:

a. Landasan Filosofi

b. Landasan Sosiologis

c. Landasan Psikopedagogis

d. Landasan Teoritis

e. Landasan Yuridis

2.4 Silabus Pendidikan Agama Hindu di sekolah Dasar

Silabus adalah rencana pembelajaran pada suatu kelompok mata pelajaran dengan tema tertentu, yang mencakup standar 
kompetensi, kompetensi dasar, materi prosedur yang relevan, dan ditulis dalam pembelajaran, indikator, penilaian, alokasi bentuk butir-butir sesuai dengan rumusan waktu, dan sumber belajar yang dikembangkan indikator pencapaian oleh setiap satuan pendidikan. Silabus paling kompetensi;f.pembelajaran, yaitu kegiatan sedikit memuat: a) Identitas mata pelajaran, yang dilakukan oleh pendidik dan peserta didik b)Identitas sekolahmeliputi nama satuan pendid untuk mencapai kompetensi yang diharapkan; ikan dan kelas;c) g) penilaian, h) alokasi waktu i) sumber kompetensi inti, d) kompetensi dasar, e) materi belajar, j) PPK.

pokok, memuat fakta, konsep, prinsip dan 
Contoh Format Silabus:

\section{SILABUS}

\section{MATA PELAJARAN: PENDIDIKAN AGAMA HINDU DAN BUDI PEKERTI}

Satuan Pendidikan: Sekolah Dasar Negeri ...............

\section{Kelas/Semester : III (Tiga) / I}

KI 1: Menerima, menjalankan dan menghargai ajaran agama yang dianutnya

KI 2:Menunjukkan perilaku jujur, disiplin, tanggungjawab, santun, peduli, dan percaya diri dalam berinteraksi dengan

keluarga, teman, guru dan serta cinta tanah air

KI 3:Memahami pengetahuan faktual dan konseptual dengan cara mengamati, menanya dan mencoba berdasarkan rasa ingin

tahu tentang dirinya, makhluk ciptaan Tuhan dan kegiatannya, dan benda-benda yang dijumpainya di rumah, di sekolah

dan tempat bermain.

KI 4: Menyajikan pengetahuan faktual dan konseptual dalam bahasa yang jelas, sistematis, logis dan kritis, dalam karya

yang estetis, dalam gerakan yang mencerminkan anak sehat, dan dalam tindakan yang mencerminkan perilaku anak

beriman dan berakhlak mulia

\begin{tabular}{|c|c|c|c|c|c|c|}
\hline & & & Alo & & \\
Kompetens & Materi & Kegiatan & & kasi & Sumber & \\
i Dasar & Pembelaj & Pembelajara & Penilaian & & Belaj & PPK \\
& aran & $\mathrm{n}$ & & $\begin{array}{c}\text { Wa } \\
\text { ktu }\end{array}$ & & \\
& & & & & \\
\hline
\end{tabular}




\begin{tabular}{|c|c|c|c|c|c|c|}
\hline $\begin{array}{l}1.1 \quad \text { Me } \\
\text { nerima } \\
\text { ajaran } \\
\text { Tri } \\
\text { Parartha } \\
\text { dalam } \\
\text { kehidup } \\
\text { an } \\
\text { sehari- } \\
\text { hari } \\
\text { untuk } \\
\text { mencapa } \\
\text { i } \\
\text { kebahag } \\
\text { iaan; }\end{array}$ & $\begin{array}{l}\text { Tri } \\
\text { Parartha } \\
\text { 1.Pengerti } \\
\text { an Tri } \\
\text { Parartha } \\
\text { 2. Bagia } \\
\text { n } \\
\text { bagia } \\
\text { n Tri } \\
\text { Parart } \\
\text { ha } \\
\text { 3. Cont } \\
\text { oh } \\
\text { Perila } \\
\text { ku } \\
\text { Tri } \\
\text { Parart } \\
\text { ha }\end{array}$ & $\begin{array}{l}\text { Mengamati: } \\
\text { a buku teks } \\
\text { pelajaran } \\
\text { agama Hindu } \\
\text { tentang } \\
\text { Pengertian Tri } \\
\text { Parartha, } \\
\text { bagian-bagian } \\
\text { Tri Parartha } \\
\text { dan contoh } \\
\text { perilaku asih, } \\
\text { punia dan } \\
\text { bhakti } \\
\text { Mengumpulka } \\
\text { n } \\
\text { informasi/Men } \\
\text { geksplorasi: } \\
\text { Peserta } \\
\text { didik } \\
\text { dibimbing } \\
\text { untuk mencari } \\
\text { dan } \\
\text { menemukan } \\
\text { sendiri arti } \\
\text { tentang } \\
\text { Pengertian Tri } \\
\text { Parartha, } \\
\text { bagian-bagian } \\
\text { Tri Parartha } \\
\text { dan contoh } \\
\text { perilaku asih, } \\
\text { punia dan } \\
\text { bhakti dalam } \\
\text { buku } \\
\text { yang tersedia }\end{array}$ & $\begin{array}{l}\text { Tugas: } \\
\text { membuat } \\
\text { laporan } \\
\text { hasil } \\
\text { pengamat } \\
\text { an atau } \\
\text { hasil } \\
\text { diskusi } \\
\text { kelompok } \\
\text { contoh } \\
\text { perilaku } \\
\text { tri pararta } \\
\text { Portofoli } \\
\text { o: } \\
\text { Menilai } \\
\text { proses } \\
\text { dan hasil } \\
\text { kerja } \\
\text { siswa }\end{array}$ & $\begin{array}{l}5 \mathrm{x} \\
4 \mathrm{JP}\end{array}$ & $\begin{array}{l}\text { • Buku } \\
\text { teks } \\
\text { pelaj } \\
\text { aran } \\
\text { Aga } \\
\text { ma } \\
\text { Hind } \\
\text { u. } \\
\text { - Buku } \\
\text { Ceritr } \\
\text { a } \\
\text { Panc } \\
\text { a } \\
\text { Tantr } \\
\text { a } \\
\text { - VCD } \\
\text { Rama } \\
\text { yana } \\
\text { - VCD } \\
\text { Maha } \\
\text { bhara } \\
\text { ta. }\end{array}$ & $\begin{array}{l}\text { - Religi } \\
\text { us } \\
\text { - Nasio } \\
\text { nalis } \\
\text { - Mand } \\
\text { iri } \\
\text { - Goto } \\
\text { ng } \\
\text { Royo } \\
\text { ng } \\
\text { - Integr } \\
\text { itas }\end{array}$ \\
\hline
\end{tabular}




\subsection{Rencana Pelaksanaan Pembelajaran Agama Hindu Terintegrasi PPK di sekolah Dasar}

Dalam proses pembelajaran membuat perencanaan pembelajaran merupakan tahapan pertama yang diwujudkan dengan kegiatan penyusunan rencana pelaksanaan pembelajaran (RPP). Setiap guru di setiap satuan pendidikan berkewajiban menyusun RPP untuk kelas di mana guru tersebut mengajar (guru kelas) di SD/MI dan untuk guru mata pelajaran yang diampunya. Untuk menyusun RPP yang benar seorang guru harus memahami hakikat, prinsip dan langkah-langkah penyusunan RPP seperti yang salah satunya tertera pada Permendiknas tentang Pembelajaran Pada Pendidikan Dasar dan Pendidikan Menengah - Pedoman Pelaksanaan Pembelajaran nomor 103 Tahun 2014. Namun peraturan ini diperbaharui dengan keluarnya Permendikbud No 23 tentang standar penilaian dan panduan penilaian terbaru.

Perbaikan selanjutnya adalah dalam mengintegrasikan Penguatan Pendidikan Karakter (PPK) didalam pembelajaran. Karakter yang diperkuat terutama 5 karakter, yaitu: religius, nasionalis, mandiri, gotong royong, dan integritas. Kurikulum 2013 merupakan kurikulum baru yang merupakan pengganti kurikulum KTSP. Dalam penyusunan perangkat pembelajaran pada tiap-tiap kurikulum memiliki model yang berbeda-beda.

Seperti yang saat ini di gunakan pada kurikulum 2013 dimana dalam pembuatan RPP kurikulum 2013 dalam komponen penyusunannya harus memuat empat hal. Keempat hal tersebut yaitu penguatan pendidikan karakter ( PPK ), LITERASI, higher order thinking skills ( HOTS ), dan 4C ( Communication, Collaboration, Critical Thinking and problem solving, dan Creativity and Innovation ).

Contoh RPP Integrasi PPK dan Literasi.

\section{RENCANA PELAKSANAAN PEMBELAJARAN \\ (RPP 1)}

Sekolah Dasar : Sekolah Dasar .............

$\begin{array}{ll}\text { Mata pelajaran } & \text { : Pendidikan Agama Hindu } \\ \text { Kelas/Semester } & : \text { VI/1 } \\ \text { Materi Pokok : Bhagawad Gita } \\ \text { Alokasi Waktu } & : 4 \times 35 \text { Menit (4 jam Pelajaran) }\end{array}$

\section{A. Tujuan Pembelajaran}

1. Siswa dapat berperilaku jujur dan bertanggung jawab

2. siswa dapat menyebutkan pengertian Bhagawad Gita sebagai kitab Pancama Weda

$\begin{array}{lll}\text { * Karakter siswa yang diharapkan : } & \text { Religius } \\ & \text { Nasionalis }\end{array}$ 
Mandiri

Gotong Royong

Integritas

B. Kompetensi Dasar dan I ndikator

\begin{tabular}{|l|l|l|l|}
\hline 1. & KD pada kI-1 & $:$ & $\begin{array}{l}\text { Menghargai kitab bhagawadgita sebagai } \\
\text { kitab suci agama hindu }\end{array}$ \\
\hline 2. & KD pada KI-2 & $:$ & $\begin{array}{l}\text { Menunjukan perilaku bertanggung jawab } \\
\text { untuk menjaga kesucian kitab bhagawadgita }\end{array}$ \\
\hline 3. & KD pada KI-3 & $:$ & $\begin{array}{l}\text { Mengenal kitab kitab suci dalam agama } \\
\text { hindu. }\end{array}$ \\
\hline 4. & KD pada KI-4 & $:$ & $\begin{array}{l}\text { Menyajikan sloka-sloka dalam } \\
\text { bhagawadgita }\end{array}$ \\
\hline
\end{tabular}

\begin{tabular}{|c|c|c|c|}
\hline 1. & Indikator KD pada KI-1 & : & $\begin{array}{l}\text { 1. Berdoa sebelum melaksanakan } \\
\text { pembelajaran }\end{array}$ \\
\hline 2. & Indikator KD pada KI-2 & : & $\begin{array}{l}\text { 2. Berdoa sesudah melaksanakan } \\
\text { pembelajaran }\end{array}$ \\
\hline 3. & Indikator KD pada KI-3 & : & $\begin{array}{l}\text { 1.Tidak nyontek dalam mengerjakan } \\
\text { ujian/ulangan/tugas } \\
\text { 2. Tertib dalam mengerjakan tugas-tugas }\end{array}$ \\
\hline 4. & Indikator KD pada KI-4 & : & $\begin{array}{l}\text { 1. Menyebutan pengertian kitab suci } \\
\text { bhagawadgita sebagai pancama weda } \\
\text { 2. Menyebutkan isi pokok Bhagawadgita } \\
\text { sebagai Pancama Veda } \\
\text { 1. Merumuskan isi Bhaagawadgita sebagai } \\
\text { kitab Pancama Weda }\end{array}$ \\
\hline
\end{tabular}

C. Materi pembelajaran

1. Bhagawadgita sebagai kitab Pancama Weda

Bhagawadgita artinya "Nyanyian Tuhan" atau" nyanyian suci." Bhagawadgita juga bernama "Gitopanisad." Bhagawadgita adalah hakekat segala pengetahuan Weda. Jiwa Bhagawadgita ada pada Bhagawadgita sendiri. Bhagawadgita juga disebut dengan nama lain yaitu Upanishad, merupakan bagian terakhir dari Weda. Bhagawadgita juga disebut weda yang ke lima atau Pancama Weda.

D. Metode : Tanya jawab,

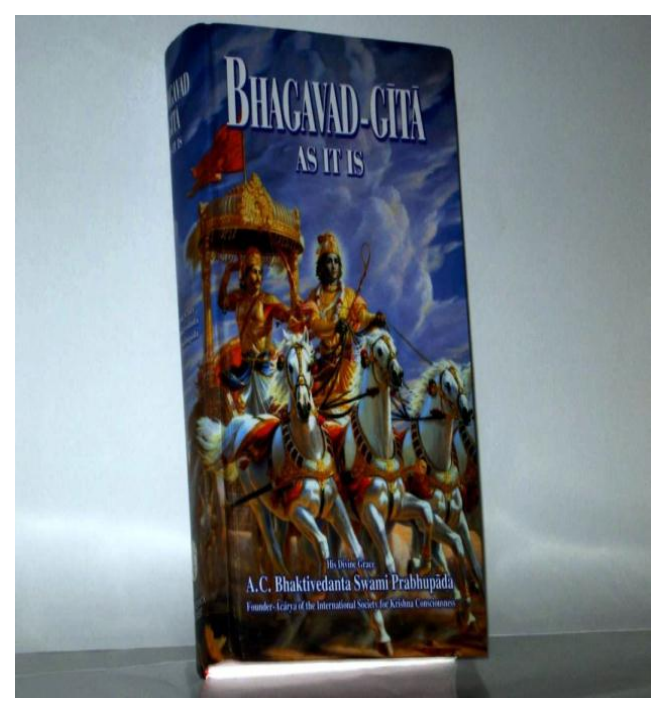

Gb 5.1 : Kitab suci Bhagavadgita (sumber : beyondheadlines.com 
kooperatif dan presentasi
1. Pendekatan
: Saintifik
2. Model Pembelajaran : Kooperatif learning
3. Metode
: diskusi, tanya jawab, presentasi dan penugasan

\section{E. Media dan Sumber Belajar}

1. Media

: Gambar , LCD dan power point

2. Sumber belajar

1. Buku Pendidikan agama Hindu dan Budi Pekerti

2. Kitab Suci Bhagawadgita

3. Upadesa

4. Buku Intisari Ajaran Agama Hindu

\section{F. Langkah-Langkah Pembelajaran}

\begin{tabular}{|c|c|c|}
\hline NO & KEGIATAN & WAKTU \\
\hline 1. & 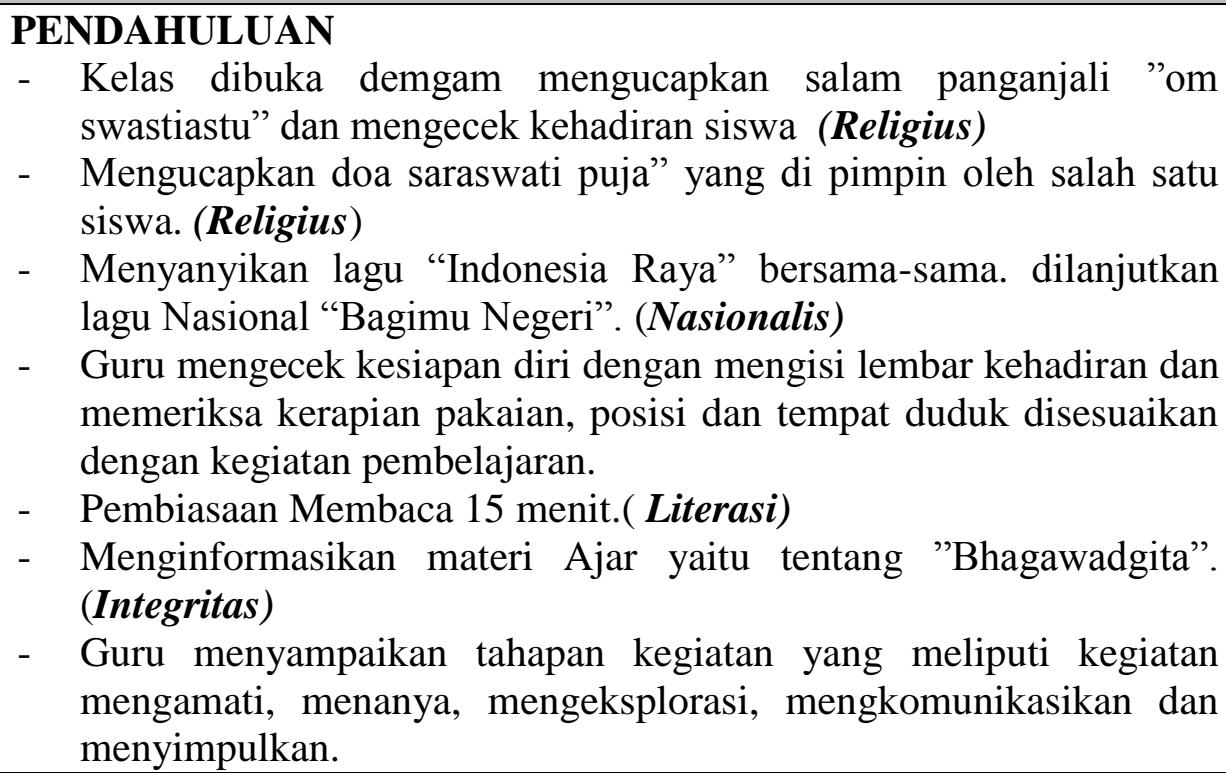 & 10 Menit \\
\hline 2 & $\begin{array}{l}\text { KEGIATAN INTI } \\
\text { Mengamati : } \\
\text { - } \text { Siswa diajak mengamati gambar slide power point yang berkaitan } \\
\text { dengan kitab suci Bhagawadgita } \\
\text { - } \text { Peserta didik membaca dengan cermat Pengertian dari } \\
\text { Bhagawadgita sebagai Pancama Veda. (Literasi) } \\
\text { Menanya : } \\
\text { - Pendidik memberikan pertanyaan pancingan kepada peserta didik } \\
\text { tentang pengertian kitab suci Bhagawadgita } \\
\text { - Setelah mendapat respon dari peserta didik, kemudian pendidik } \\
\text { menggugah peserta didik untuk bertanya lebih mendalam terkait } \\
\text { dengan pengertian suci Bhagawadgita sebagai Pancama Weda. }\end{array}$ & 80 Menit \\
\hline
\end{tabular}




\begin{tabular}{|c|c|}
\hline & $\begin{array}{l}\text { - Dengan sikap santun dan jujur siswa bertanya kepada guru tentang } \\
\text { pengertian kitab suci Bhagawadgita sebagai Pancama Weda. } \\
\text { (Mandiri) } \\
\text { Mengeksperimen } \\
\text { - Setelah peserta didik, melihat tayangan slide power point, } \\
\text { membaca, bertanya dan mendengar tentang pengertian sebagai } \\
\text { Pancama Weda, pendidik memberikan arahan kepada peserta didik } \\
\text { untuk mencari informasi melalui diskusi kelompok untuk berbagi } \\
\text { informasi tentang pengertian kitab suci Bhagawadgita sebagai } \\
\text { Pancama Weda, hasil diskusi kelompok dalam rangka membangun } \\
\text { sikap positif dan disiplin tentang pengertian Bhagawadgita sebagai } \\
\text { Pancama Weda } \\
\text { Mengasosiasi : } \\
\text { - Setelah peserta didik membaca, mendengar, mengumpulkan data } \\
\text { tentang pengertian Bhagawad Gita } \\
\text { Kemudian pendidik meminta peserta didik Secara berkelompok } \\
\text { siswa mengolah imformasi tentang pengertian Bhagawad Gita } \\
\text { (Integritas) } \\
\text { Siswa secara berkelompok bertukar informasi tentang pengertian } \\
\text { kitab Bhagawad Gita (Collaboration) } \\
\text { - Sengkomunikasikan : } \\
\text { - } \\
\text { metelah peserta didik mengamati, menanya, menganalisis dan } \\
\text { pendidik memberikan kesempatan kepada peserta didik untuk } \\
\text { menyampaikan secara lisan ke depan kelas secara bergiliran tentang } \\
\text { pengertian Bhagawad Gita } \\
\text { kedepan kelas. Setelah peserta didik menyampaikan laporannya di } \\
\text { depan kelas, kemudian pendidik memberikan penguatan mengenai } \\
\text { tentang pengertian Bhagawadgita sesuai } \\
\text { pembelajaran. } \\
\text { - }\end{array}$ \\
\hline 3 & 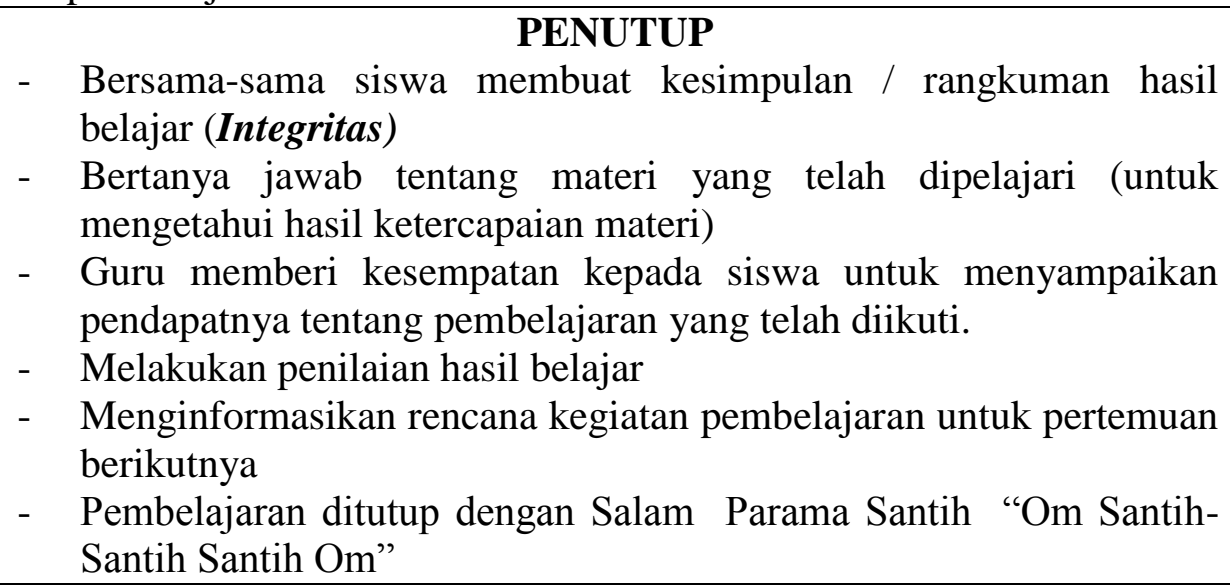 \\
\hline
\end{tabular}




\section{G. Penilaian}

1. Penilaian sikap :

Sikap spiritual : Observasi (terlampir)

Sikap sosial : observasi dan penilain diri (terlampir)

2. Penialan Pengetahuan :

$\sim$ Teknik

: tes tulis, dan penugasan

$\sim$ Bentuk

: isian

3. Keterampilan : praktik unjuk kerja

\begin{tabular}{|c|l|c|}
\hline No & \multicolumn{1}{|c|}{ Indikator } & Butir Instrumen \\
\hline 1 & Pengertian Bhagawad Gita & 2 \\
\hline 2 & Isi Bhagawad Gita & 3 \\
\hline
\end{tabular}

\begin{tabular}{|c|c|c|c|}
\hline NO & $\begin{array}{l}\text { JENIS } \\
\text { PENILAIAN } \\
\text { (KI.3) }\end{array}$ & URAIAN & KET \\
\hline 1 & TUGAS & $\begin{array}{l}\text { Pendidik menugaskan kepada peserta } \\
\text { didik untuk mengerjakan soal-soal } \\
\text { pada buku LKS di rumah. }\end{array}$ & $\begin{array}{l}\text { Butir soal yang } \\
\text { dikerjakan berdasarkan } \\
\text { kesepakatan peserta } \\
\text { didik dengan pendidik. }\end{array}$ \\
\hline 3 & TES TULIS & $\begin{array}{l}\text { Jawablah pertanyaan di bawah ini } \\
\text { dengan benar } \\
\text { 1. Bhagawad Gita artinya.... } \\
\text { 2. Kitab yang disebut sebagai } \\
\text { Pancama Weda adalah.... } \\
\text { 3. Jumlah bab yang terdapat dalam } \\
\text { kitab Bhagawadgita adalah.... }\end{array}$ & $\begin{array}{l}\text { Kunci Jawaban } \\
\text { 1. Bhagawadgita } \\
\text { artinya "Nyanyian } \\
\text { Tuhan" atau" } \\
\text { nyanyian suci." } \\
\text { Bhagawadgita juga } \\
\text { bernama } \\
\text { "Gitopanisad." } \\
\text { Bhagawadgita } \\
\text { adalah hakekat } \\
\text { segala pengetahuan } \\
\text { Weda Lima dasar } \\
\text { keyakinan atau } \\
\text { kepercayaan bagi } \\
\text { umat Hindu. } \\
\text { 2. Bhagawad Gita. } \\
\text { 3. 18 Bab. }\end{array}$ \\
\hline
\end{tabular}


PEDOMAN PENSKORAN :

1. TUGAS

\begin{tabular}{|r|l|c|}
\hline NO & \multicolumn{1}{|c|}{ KRITERIA } & SKOR \\
\hline 1 & Ketepatan menjawab masing-masing soal & \\
\hline 2 & Ketepatan waktu mengumpul & \\
\hline & & \\
\hline & Nilai = (Jumlah skor perolehan/Skor ideal)*100 & \\
\hline
\end{tabular}

2. TES TULIS

\section{Kreteria penskoran :}

Skor 0 jika tidak dijawab

Skor 1 jika jawaban mendekati benar

Skor 2 jika jawaban benar

\section{Skore $=$ Skor Perolehan Peserta didik $\times 100 \%$ Skor maximal}

\section{I.4 KETERAMPILAN (KI.4)}

a. Teknik : Portofolio

b. Bentuk Instrumen : "Pendidik menugaskan kepada peserta didik membuat tabel yang menguraikan tentang Isi Bhagwad Gita dan jumlah slokanya

c. Kisi-kisi : sesuai dengan babnya masing-masing.

Komponen Portofolio: Skor Maksimum perolehan nilai adalah 100 dengan aspek penilaian sebagai berikut:
1. Kerapian
$=100$
2. Ketepatan isi berdasarkan bab $\quad=100$
3. Sistematika penulisan
$=100$

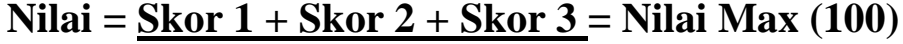


Kepala SD

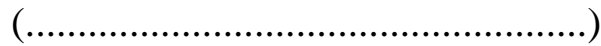

NIP.
Guru pendidikan agama Hindu

Pendidikan Agama Hindu dan Budi Pekerti,

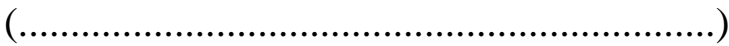

NIP.

\section{Penutup}

Melalui kurikulum pendidikan agama yang ada, guru pendidikan Agama diharapkan mampu melakukan integrasi pendidikan karakter melalui pendekatan intrakurikuler, cokurikuler, ekstrakurikuler dan pembiasaan atau keteladanan. Pada pendekatan intra-kurikuler mata pelajaran pendidikan agama, praktek implementasinya dilakukan (sejak) melalui tahap perencanaan pengajaran, proses instruksional, dan evaluasi. Pada tahap perencanaan maka silabus, RPP, kompetensi inti (KI), dan kompetensi dasar (KD), serta materi pembelajaran pendidikan agama disinkronkan dengan aspek-aspek nilai karakter. Dalam dokumen perencanaan pembelajaran (RPP), nilai-nilai karakter dinyatakan pada setiap pokok bahasan. Guru agama melakukan eksplorasi, elaborasi dan konfirmasi terhadap nilai-nilai karakter yang relevan.

\section{DAFTAR RUJUKAN}

Kemendikbud. (2017). Konsep dan Pedoman Penguatan Pendidikan Karakter. Buku . Jakarta. Balitbang Kemendikbud

Kementrian Pendidikan Nasional. (2016). Panduan Pelaksanaan Pendidikan Karakter. Jakarta. Balitbang Kemendikbud

Kemendikbud. (2016). Buku Pegangan Guru Pendidikan Agama Hindu . Jakarta. Balitbang Kemendikbud.

Sudyana. (2018). Integrasi PPK dalam Proses pembelajaran. Makalah tidak terbitkan,Denpasar. 